\title{
特集【論説】 大規模集客施設の郊外立地規制について考える
}

\section{「大規模集積施設の郊外立地規制（改正都市計画法）についての エコノミストの考え方」 \\ Economist's View on Renewed Urban Planning Law ; \\ Limited Location of Large Scale Shopping Mall at Suburban Area}

Kazumi KUROKAWA : Hosei University

黒川 和美*

Urban Planners Have Been Requiring New Urban Planning Procurement and Urban Vision Set up Every Urban Area in Japan, Because Existing One Doesn't Have Enough Controlling Over Land Use Based on Total Vision. They Usually Make City Plans from City Center Cores Which Stock Urban Infrastructures, Road, Rail, Water Facilities, School, Governmental Office, Business Office, Hospital, Shopping Space and so on.

In Spite of Their Ideal Vision and Plan, Around Urban Periphery Developer Made Big Projects, Shopping Mall, Cinema Complex and Local Government Locate Public Facilities, Hospital, Apartments, Schools.

Japanese People Now Consider Sustainable Compact City Concept Needed Rather Than Economic Growth Structured by Population Less-Growth Age.

Economists Can Agree Some Parts of Urban Planer Ideas. Urban Planning With Total Visions, Efficient Urban Social Capitals Using, More Developed Center Cores. But Economists Require Keeping Competition Between Urban And Suburban Land Use. If Suburban Location Regulation Introduced, Land Owner in Center Core Area Can Possibly Get Monopolistic Rents. For Efficient Competitive Center Core,Economists Require Competitive Land Use Not Only Among Center Core Area But Also Between Urban And Suburban.

Economists Also Admit Some Certain Regulation on Suburban Developments in The Case of Technological Externalities Cancelled Out by Levying Pigoubian Tax.

keywords: Renewed Urban Planning Law, Compact city, Externality, Urban Social Capitals, Rent-seeking 改正都市計画法, コンパクトシティ, 外部性, 都市インフラ, レントシーキング

\section{はじめに}

まちづくり三法（改正都市計画法など）が平成 18年 5 月末に交付された。この改正は社会資本整
備審議会第一次答申（新しい時代の都市計画はい かにあるべきか) において（人口減少・超高齢社 会を迎え，都市機能の無秩序な拡散に歯止めをか け，都市の既存ストックを有効活用しつつ，都市 
圈内で生活する多くの人々にとって暮らしやすい 集約型都市構造を実現していくことが必要であ る）という提言に基づき，都市の構造に深刻な影 響を及ぼす可能性のある大規模集客施設について は機能的な都市構造を確保するために立地を制限 しょうと考える立場にある。

これに対して大規模店舗などの立地規制に対し その手段が土地利用規制となることから内閣府の 規制改革・民間開放推進会議から（新たな法律的 仕組みで立地規制をしようとする試みは既存の競 合する店舗などとの競争を抑制することになる需 給調整や既得権擁護とならないように措置すると ともに，環境悪化，交通渋滞の悪化，都市基盤施 設の利用効率の低下，集積による利便の増進など 土地利用の外部性をコントロールする観点から運 用されるべきである）という答申が行われた。

これからのまちづくりは都市の拡大成長の時代 から人口減少時代に適合したものへと転換する。 都市の運営コストの増加を抑制し, 自動車利用が 困難な高齢者や若年者などを含む，多くの人々に とって暮らしやすい都市構造を実現することが都 市政策として求められている。特に中心市街地活 性化の問題が全国の，特に地方の核となる都市に おいて発生しており，都心居住や公共公益施設設 置など集積促進策が計画的で整合性を持った地域 政策の中で総合的に取り組まれなければならない。 がしかし，これまでは都市計画の運用がこうした 取り組みと連動せず単なるレントシーキング（適 切な競争力の維持に努力せず，自己の利益を守る ために規制に頼り，競争を抑制し，新規参入者を 排除するために政治的意思決定に資金を投入する ことから社会に負担をもたらす非効率, 企業の参 入規制）に陥り，経済活動に対する不必要な制限 を生み出す傾向が生じてきている。そこで本論で は都市計画に関心を持つエコノミストの立場から まちづくり三法の改正について思うところを述べ てみたい。

\section{1. 都市集積の考え方について}

この問題には多くの都市計画関係者の思いが込 められている。たとえば，曖昧な土地利用を容認 する未線引きの土地がなくなり，土地利用の問題 が確立するとその土地利用ルールを基礎に財産権 が適切に確定し，土地利用市場が成立し，土地利 用に関する競争関係が生まれる。欧州型の都市計 画制度が確立できるのだ。これまで都市計画区域 でありながら未線引きの土地がある一方，都市計 画地域と農業振興地域との間にその利用が不透明 なエリアが計画的であれ偶然であれ作り出されて きている。農業土地利用においても適切に農業を 振興するための農地が確保されなければならず, また，都市地域からすると，適切な社会資本整備， インフラの整備によって都市の成長を適切に誘導 し集積の外部効果を計るように必要な上下水道や エネルギー資源，鉄道，道路などの交通インフラ を整備する。さらには土地の集積を促進する学校, 図書館, 医療施設など多くの人々が必要とする公 共施設の整備なども市民の生活にもっとも利便で, かつ効率的な社会資本の整備である。結果として 都市の集積をほこるセンターコアエリアが作りだ されるはずだ。しかしこのセンターコアエリアは なぜか適切な投資がこれまでは行われにくく，結 果として急速に浸透したわが国の自動車社会のあ り方にキャッチアップすることができない。鉄道 駅前型中心市街地は平地の駐車場などに支配され， 車社会の利便性は土地利用規制の無いいわゆる曖 昧な郊外エリアに大規模集約施設が立地する状況 を作り出してきた。中心市街地は自らその集積を 失うような今から考えると患かな行為をたくさん 繰り返してきている。集積の基礎となる中心市街 地の居住者はその土地を担保に，より居住環境の 良い郊外に家族の住宅を確保し，中心市街地の居 住人口はピーク時と比較にならないほど減少して いる。現に公共施設の多くは中心市街地に整備さ 
れていたが, 役所の片舎や総合病院, 郵便局など が車でアクセスし易い開発可能な郊外地域に進出 し，中心市街地はあえてその集積の力を薄めて来 た。平地駐車場を作ることで郊外の沿道沿いの商 業施設と車社会の中で競争するという対応に終始 してきた。郊外には中心市街地をバイパスする道 路が整備され, その沿道には自動車社会に適用し た全国展開するフランチャイズ型のさまざまな店 舗が展開し, 中心市街地活性化法が整備された時 点でもう既に整備された中心市街地基本計画は有 効に機能することが困難な状況に陥っていた。

経済学者は都市計画家よりも土地利用について よりダイナミックに捉えるのが普通である。この 戦後の 60 年でも経験したように私たちを取り巻く 産業構造はどれほど普遍的なものと想定しても歴 史のほんの一幕にすぎず，その変化は私たちの想 像をはるかに超えてきた。建築基準法で想定する 用途容積は都市計画手法が確立し, 農業用途の土 地利用と都市計画用途の土地利用が完全に地図を 覆うとき, 工業地域が少しずつ削られ, 農業地域 が少しずつ削られ，いわゆる「スプロールと滲み 出し」によって一方で曖昧な準工業地域に土地の 高度利用が進み，住宅やオフィスが展開し，また， 公共施設などが農地側に広がってきた。

例えば，わが国は第 3 次産業が $80 \%$ 超え, 当然 就業者の数も圧倒的にサービス産業に依存し, 多 くの人々の所得はサービス産業依存になっている が，わが国の国土利用計画では今でも海岸線に大 規模な工業を予定し，また，ネットワークされた 高速道路沿いには内陸型の工業用地が数多く保持 され，低度，未利用のまま保持されている。今回 の大規模店舗の郊外立地規制問題はこの内陸型工 業団地の土地利用転換が進み始めるとき, より大 きな問題を改めて引き起こす。なぜなら中心市街 地には札幌, 仙台, 横浜, 名古屋, 京都, 大阪, 神戸，広島，福岡などの中枢中核都市では地下鉄 や新都市交通システムが整備され, 鉄道ネット
ワークによるインフラの整備が進んできている。 しかし，いま少し規模の小さいいわゆる地方中核 都市や県庁所在地では中心市街地を構成する交通 手段はバスが中心でわずかにトラムや L R Tがい くつかの都市で活躍しているにすぎない。公共交 通が十分に整備され, それによって日常生活が利 便に維持されている公共交通依存型の中心市街地 機能を保有する地域では, 都心居住を促進するこ とで人口減少時代に対応する都心の集積を維持す 続けることができるかもしれないが，多くの場合， 中心市街地に立地する大型店はその土地利用の非 効率性から撤退し, 低度未利用の土地が数多く生 み出されてきている状況にある。

未線引きの土地が存在し，それをより低コスト で利用できるため大型店が立地するという構造か ら, 都市計画手法が確立し, 都市と農村の境界が 明確になり, 結果として土地計画区域内での都心 と郊外, センターコアとペリフェリーの競争関係 が既存の社会資本整備水準を基礎に低度未利用に なっている都心空地と地価の安いバイパス沿いの 土地との間での競争が進行しているのだ。

\section{2. 国と地方の関係}

まちづくり三法の改正の背景について考慮して おかなければならない問題の一つに, 国と地方の 関係がある。2000年の地方分権推進一括法以来, 国と地方の関係はある意味で法的には対等になっ ている。実際，必ずしも国の地方に対する優位性 は変わっていないが, 都市計画手法においても国 は一定の制約を地方に対して加える必要があると 考えている。都市計画の改訂を行う場合, 基本的 には土地利用変更許可権限は知事に与えられてい るため, 国と地方の関係は国, 都道府県, 市町村 の関係でもある。基礎的自治体は自分達の町を自 分たちのまちの振興を考え, それに必要な地域政 策を実施し，その土地利用が有効であれば人口が 増加し, 中心市街地に商業業務が集積し, 固定資 
産税収入や都市計画税収入が増加する。しかし， 全国の市町村が闇雲に競争に走ると，過当競争に 陥り，税減免制度の乱発が発生する。また，都道 府県は市町村に対し，もっぱら企業誘致を誘導す る。広域のインフラ整備を行ってきている都道府 県はそのインフラを有効活動されるように土地利 用を誘導し, 結果として都道府県の主要な税収と なる事業所税収入を確保することができる。国は 国土利用計画を立て，その土地利用が全国で整合 的になるように都市地域や農業地域や山林地域の 量を想定している。しかし，国の想定する人口や 産業構造の変化はこれまでのところ，ことごとく 楽観論で，計算間違いを犯してきた。産業構造の 予測も狂っているし，それゆえ国の指導的な地位 は常に後追いの形になっている。

近年，あらゆる行政分野において国と地方の関 係が見直される傾向にあるが，土地利用規制にお いてもその重要な課題になっている。国と地方の 関係と考える場合，国は多くの場合都道府県の担 当者の意見を聞いている。しかし, 都道府県の担 当者と市町村の担当者の間で大きな意見の相違が ある。まして, 自治体を先導している知事や市長 は意欲的に地方分権の実をとろうとしているが, 都道府県の職員は優秀であればあるほど国の方針 を正確に理解し，都道府県行政に持ち込もうとし ている。それゆえ, 都道府県が作成する総合計画 や市町村が作成する総合計画は，それぞれの魂は 宙に浮いたまま全国一律のデー夕整備型総合計画 に終始する傾向にある。

\section{3. 都市空間活用と競争政策}

地方の核となる中規模の都市をイメージすると， 都市計画関係者が期待するように都市の中心セン ターコアエリアがかつての（自動車社会が一般化 する以前の）中心機能をより発展させているとこ ろは，考えているほど多くはない。

1. 中心市街地に人が住まなくなっている。し
かし東京の都心居住が進展しているように，地方 都市においても都心居住の傾向が生まれているこ とは確かだが，昭和 30 年代中頃と比べると，押し なべて中心市街地の人口は半分以下になっている。 つまり，よりよい居住環境を求めて中心市街地で 事業を営んでいた人々も郊外に移り住んでいる。

2. 自動車社会に行政サービス自体がうまく供 給対応できなかった。どの都市でも見られること だが，病院や郵便局，大型店，役所などは中心市 街地に駐車場などのインフラが整備されたにも関 わらず，より自動車社会に利便な郊外の道路沿い に移転している。つまり, 今, 中心市街地に再集 積をはかったとして, 都心の機能が高度化するか どうかについては疑問がある。

3. 中心市街地に果たしてインフラの集積がど の程度あるのだろうか。多くの都市では中心市街 地に鉄道駅があり，バスターミナルがあり，交通 の結節点の機能を果たしている。しかし，昭和 30 年代 40 年代の我々の想定をはるかに超えて日本の 経済は拡大し, 空間当りの生産力も大幅に高まっ ていっている。現在ストックとして集積されてい る地方核都市のインフラストックは果たして再集 積を求めるのに十分なだけの潜在的な空間活力を 備えているかどうか疑問になる。

4. 最も深刻な問題は中心市街地で区画整理事 業が予定通り進行しなかったことだ。中心市街地 の土地利用が家業型商業者に委ねられ, 彼らの協 力が十分に得られなかったことが時代に適用した 特に自動車社会に適用した商業集積を中心とした 都市集積を確保できなかった。例えば，中心市街 地に現行以上の高度利用高い容積率を認めていた ら，自動車社会に対応したインフラ整備や沿道拡 大によるLRTなどの導入も可能であったかもし れない。中小工場農業商業は, 家業型でその所有 する不動産を効率的に活用する都市の都心機能を 担うだけの高度利用を推進することが残念ながら できなかった。 
5 . 最も重要な要因は人々の日常生活圈が急速 に拡大したということである。道路が整備され, 鉄道の利便性も高まると, 人々のライフスタイル はそれによって変化し, 人々の日常生活圈いわゆ るテリトリーは大幅に広がっている。地方都市で は鉄道を利用するのが高校生などに限定され，多 くの働き手は自動車に依存している。

様々な要素からわかるように, 今新たな都市ビ ジョンを策定し，これまで培ってきた都市の形状 をよりコンパクトで将来の人口減少に備えて, 省 エネルギーで車に頼らず，公共交通に依存する体 質に変えていくには，相当な努力が必要であると 思われる。もちろん, 東京や大阪, 名古屋, 札棍, 仙台, 京都, 神戸, 広島, 福岡といったいわゆる 地方中枢中核都市では都心にセンターコアとなる 鉄道駅があり，それらとネットワークする地下鉄 やバス輸送がシステマティックに整備され, 都心 部の業務機能は家業型の商業には依存せず, 土地 利用は区画整理事業を通して大規模化し高度化し ており，現在以上にコンパクトな都市空間活用が 可能となる可能性がある。

\section{4. 都市ビジョン確立の可能性}

中心市街地に集積があり，それを支えるインフ ラもストックされている。このような場合にそれ ぞれの都市はどのような都市ビジョンを描きうる だろうか。中心市街地は人々が日常的に集う空間 であり，毎日一度はそこに足を運ぶ，そのような 場所として存在する。例えば,

1. 地域の顔として中心市街地には歴史的な建 造物や大規模公園, 行政施設, 高等教育機関, 総 合病院, 情報通信拠点としてのNTTや郵便局が立 地し, 町の顔としてそのたたずまいを備えている， と考えられる。鉄道駅があり，国道が通過してい る。ここに地下鉄や都市型新交通システムLRT, トラム, バス, などのネットワークがリンクし, 誰もがこのエリアに日常的にアクセスすることに
なる。これらの顔を失うことは都市にとって致命 的な打撃を与える。典型的な中心市街地の都市ビ ジョンを描くことができる地方核都市は果たして どれほど存在するのだろうか。

2 . 環境拠点 都市ビジョンの新たなコンセプ トとしてコンパクトシティ論が論じられている。 公共交通で人々は移動し, 食住接近しており, 中 心市街地に人々がなおも居住している。周辺の農 村地域から日常的に新鮮な野菜や果物, 酪農製品 が届けられ，人々はそれらの季節に彩られた作物 を歩ける範囲，自転車で移動できる範囲で手にす ることができ, 都市で排出される有機物は周辺の 農地に循環され, $\mathrm{CO}_{2}$ を削減し, 窒素循環を確保 した小規模な中心市街地の典型的なビジョンであ る。このコンパクトシティの概念が日本に適用さ れるためには，どのような工夫が必要だろうか。 人々がまず都心に居住し始めなければならない。 人々は自動車を利用せず，職場に行き，また日常 生活を遂行できるヨーロッパの環境都市と呼ばれ る多くの都市ではこの条件を満たしている。

3. 高齢化社会が進行することと人々の生活の 利便は福祉の拠点としての機能を中心市街地が果 たすことで都市の交通システムはシームレスでバ リアフリーでなければならない。介護サービスや リハビリのために人々はできるだけ容易に都心に アクセスでき, 特に高齢者は都心機能を十分に享 受できるそのような社会資本ストックを中心市街 地は備えていなければならない。

4. 情報拠点としての都心 季節感や人々が都 心に集う必然性を作り出す都市を取り囲む農村地 域に固有の季節感を求めることができる。都市の 広場では周辺農村で育てられた柿が並び, 周辺農 村でとれた野菜や果実が手に入り，都市が提供す る公共サービスやイベントの情報が地域FMや都 市型CATVを通じて人々に新鮮な情報として届 く。都心はある種の情報拠点でなければならず, そこには多くの情報発信を仕事とする事業者が集 
積している。

5. 交通の結節点としての都心 日常的に通勤 通学で都心に触れるメカニズムがあれば，人々は おのずと都心を交通の結節点として活用すること になる。鉄道駅，地下鉄，新都市交通LRT，トラ ムなどの軌道形交通システムは都心に高度な機能 を集積させる主要なインフラとなり，エネルギー， 水，水処理などと共にライフラインを提供する拠 点となりうる。

都市のビジョンを確立しようとすると，都市の 生い立ち, 都市の規模, 都市の機能などに大いに 依存することになる。都市計画家のイメージする 理想の中心市街地は地域の顔や環境制約，情報拠 点機能, 福祉サービスなどが日常的に供給される。 しかも高度な付加価值の高い業務サービスが機能 する都心に人々が居住しているという想定になる。 果たして現状を考えるとこのような理想的な都市 ビジョンを描くことが可能な地方の拠点となる都 市はどれほど存在するのだろうか。中心市街地活 性化基本計画が作られた都市は670を数える。しか し，今その計画がなかなか前進できない。そして しばしばその理由を自動車社会の弊害と見なそう としている。

\section{5.エコノミストの見解}

エコノミストは土地利用についても消費者主権 いわゆる需要サイドに立って消費者の選択が最も 優れたものと考える。自動車社会は確かに来る心゙ き高齢化社会に運転能力を持たない高齢者や若年 者を排除する可能性を持ち，もし仮に公共交通が 人々の不便をなくし，〈まなくネットワークされ ているのであれば，人々が郊外の大規模集客施設 に引き付けられようが, 都心の中心市街地に引き 付けられようが，あるいはその両者が互いに競い 合うことで消費者の利便性がさらに高まっていく のであれば，それが最も望ましい姿であると考え る。
大規模集客施設の郊外立地規制を必要と考える 人々は駅を中心とした中心市街地にこれまでも多 くの資金が社会資本整備として投資され，交通 ネットワークは整備され, 都心の土地の高度利用 が可能になっているにも関わらず，より安価に郊 外の沿道に立地できることによって，中心への集 積が抑制されている。もし中心市街地に十分なス ペースがあり，中心市街地により便利な交通ネッ トワークが整備されており, その地代が十分にそ の土地の魅力を現しているものであれば，あえて 郊外に周辺への負の外部性を抑止し，より多くの 設備投資をして，事業者は郊外に立地する必要は ない。しかし，郊外には都市計画未線引き地域が なおも数多く存在し, また, 農村地域には農地の 転用が可能になる安価な大規模敷地が存在してい ると道路，上下水道，エネルギー施設，大規模駐 車場などを自前で整備しても中心市街地より効率 的に事業を遂行する可能性があるという点を示し ている。

さらに，郊外に大規模店が立地することを規制 し，中心市街地に大規模店を誘導することが可能 であれば，それは中心市街地の土地利用の効率性 を示すことになる。しかし，中心市街地の土地利 用はしばしば旧来の地権者が相続や納税を意識し てその土地利用を共同化し，大規模化して効率的 な活用に委ねることを妨げているかもしれない。 特に, 中心市街地の居住者がピーク時の半分以下 に減少し，多くの人々がかつての中心市街地の居 住者をも含めて郊外に居住しているとすれば, 中 心市街地活性化空洞化対策の更新に必ずしも市民 はイエスと判断しないかもしれない。多くの市民 は週末自動車に依存して大型店に買出しに出る。 そのようなライフスタイルがまもなく果たして終 わり，多くの人々が今一度中心市街地に興味を抱 くことは生じるのだろうか。都市のビジョンを描 かなければならない自治体の都市計画担当者は郊 外開発か中心市街地の再開発かで大いに頭を悩ま 
すことになるだろう。ただし, 中心市街地の土地 の共同利用による高度化を妨げている地権者が郊 外の立地規制に大いに政治力を発揮して中心市街 地の地権者として利益を得るように努力をすれば, これは公平な競争を明らかに阻害し, 自分達の利 益を守るために中心市街地に立地誘導を図って地 権者の利益を守ろうとしているのかもしれない。 重要な点は地権者が再開発土地区画整理事業など に積極的に協力し, 中心市街地が郊外よりもより 活用しやすく，市民にとってよりよい選択となる ものでなければならない。
現在都道府県は市町村に企業設置を呼びかけて いる。しかし多くの市町村には産業構造の著しい 変化から内陸型工業用地, そして, 港湾地域, 臨 海工業用地の用途転用が求められてくる筈だ。こ の認可は知事に与えられた権限であるが, 市町村, 県それぞれ長期的な経済構造の変動を予測し, そ れぞれの立地について相対的な評価を与えてゆか なければならない。果たして，行政はこのような 判断を適切に行なえる能力を有しているのだろう か。 